JKEP

Vol 3, No 2, November 2018

ISSN: 2354-6042 (Print)

ISSN : 2354-6050 (Online)

\title{
Tingkat Pengetahuan Siswi SMK Sentra Medika Medan tentang Premenstruasi Syndrome (PSM)
}

\author{
${ }^{1}$ Dina Indarsita, ${ }^{2}$ Salbiah, ${ }^{3}$ Novi Tesalonika Hutahaean \\ ${ }^{1}$ Jurusan Keperawatan Poltekkes Kemenkes Medan \\ ${ }^{2}$ Jurusan Analis Kesehatan Poltekkes Kemenkes Medan \\ ${ }^{3}$ Jurusan Keperawatan Poltekkes Kemenkes Medan \\ Email: salbiah.khamaruddin80@gmail.com
}

\begin{abstract}
Premenstrual syndrome (PMS) is one of the most common disorders in women. Severe symptoms of PMS can cause absenteeism at school or at work. Improving your lifestyle by increasing physical activity and a healthy diet can reduce the occurrence of PMS. The purpose of this study was to determine the level of knowledge of Medan Vocational High School students about PMS. Research was conducted from January to July 2017. The number of research samples was 86 people. Sampling was done in Accidental Sampling. Data is obtained by filling out questionnaires and descriptive research methods. The results of the study found that most of the respondents' level of knowledge was good at $64.0 \%$, the source of information about 50\% PMS came from health workers. $76 \%$ of female students have good knowledge about preventive measures against PMS. The results of the study show that with good knowledge, the PMS problem can be overcome
\end{abstract}

Keywords: Knowledge; prevention; premenstrual syndrome.

\begin{abstract}
ABSTRAK
Premenstruasi syndrome (PMS) merupakan salah satu gangguan yang paling umum pada wanita, PMS yang sangat parah dapat menyebabkan ketidakhadiran di sekolah ataupun di tempat kerja. Memperbaiki gaya hidup dengan meningkatkan aktivitas fisik dan pola makan yang sehat dapat mengurangi terjadinya PMS. Tujuan dari penelitian ini untuk mengetahui tingkat pengetahuan siswi SMK Sentra Medika Medan tentang PMS. Penelitan dilakukan pada bulan Januari sampai dengan Juli 2017. Jumlah sampel penelitian 86 orang. Pengambilan sampel dilakukan secara Accidental Sampling. Data diperoleh dengan cara pengisian kuesioner dan metode penelitian bersifat deskriptif. Hasil penelitian ditemukan sebagian besar tingkat pengetahuan responden adalah baik yaitu sebesar $64,0 \%$, sumber informasi tentang PMS 50\% berasal dari tenaga kesehatan. Sebanyak 76\% siswi memiliki pengetahuan yang baik tentang tindakan pencegahan terhadap PMS. Hasil penelitian memperlihatkan dengan pengetahuan yang baik, maka masalah PMS dapat diatasi.
\end{abstract}

Kata kunci: Pengetahuan; pencegahan; premenstruasi syndrome 


\section{PENDAHULUAN}

Premenstruasi Sindrome (PMS), merupakan gangguan siklus yang umum terjadi pada remaja putri, ditandai gejala fisik dan emosional yang konsisten, terjadi selama fase luteal pada siklus menstruasi. Secara kultural, singkatan PMS dipahami secara luas untuk mengacu pada berbagai kesulitan yang dihubungkan dengan menstruasi, dan singkatan itu digunakan lebih sering bahkan dalam peristiwa sehari-hari (Saryono \& Waluyo, 2009). Berdasarkan penelitian Coryna Rizky Amelia (2014), di kota Malang pada siswi SMP di dapatkan hasil $77,4 \%$ responden memiliki tingkat pengetahuan baik, 22,6\% responden memiliki tingkat pengetahuan yang cukup dan tidak ada responden yang memiliki tingkat pengetahuan kurang. Penelitian sejenis juga dilakukan oleh Badriyah (2013), pada siswi kelas XI di SMA N 3 Sragen dengan hasil pemahaman siswa tentang Premenstruasi Sindrome (PMS) dengan kategori baik sebesar $62,5 \%$, kategori cukup sebesar 28,75\%, dan ketegori kurang sebanyak 8,75\%.

Sampai saat ini penyebab PMS belum bisa dijelaskan secara ilmiah. Beberapa teori menyebutkan pre menstruasi syndrome terjadi karena ketidakseimbangan antara hormone esterogen juga bisa menimbulkan pre menstruasi syndrome.walaupun demikian, PMS biasanya lebih mudah terjadi pada remaja putri yang peka terhadap perubahan hormonal dalam siklus haid (Nugroho \& Utama, 2014 ). Menurut Sukami \& Wahyu 2013, sekitar $80-95 \%$ remaja putri mengalami gejala - gejala pre menstruasi yang menggangu beberapa aspek dalam kehidupannya. Gejala tersebut dapat diperkirakan dan biasannya terjadi secara regular pada dua minggu periode sebelum menstruasi. Hal ini dapat hilang begitu dimulainya menstruasi, namun dapat pula berlanjut setelahnya. PMS ditandai dengan perubahan yang cepat dalam suasana hati (misalnya depresi, iritabilitas,kemarahan, agresi, mudah menangis, kecemasan, dan gejala fisik (misalnya, ketidaknyamanan payudara, nyeri pada perut, sakit kepala, kembung) selama fase luteal akhir siklus menstruasi.

Sebagian remaja merasa cemas ketika menghadapi PMS. Penyebab pasti munculnya kecemasan dalam menghadapi premenstruasi syndrome diantarannya adalah faktor hormonal dalam tubuh remaja, yaitu ketidakseimbangan antara hormone estrogen dan progesterone. Kecemasan yang tidak diatasi segera akan menimbulkan berbgai respon kecemasan, antara lain gelisah, keringat dingin, takut dan berbagai gangguan kesehatan yang dapat menggangu aktivias sehari-hari (Yani, 2011). Kurangnya pengetahuan 
pada remaja putri tentang PMS dapat memperberat gejala yang dirasakan sehingga menimbulkan kecemasan (Maryati.,2011). Penelitian yang dilakukan oleh Miftahul Khoyriyah di SMP Muhammadiyah 2 Surakarta pada tahun 2014 melaporkan bahwa $60 \%$ siswa bersikap positif, terhadap PMS. Studi pendahuluan yang dilakukan penulis di SMK Sentra Medika Medan didapatkan bahwa $80 \%$ remaja putri tidak mengetahui tentang PMS.

Populasi remaja di kota Medan berdasarkan data badan pusat statistik (BPS) kota medan, di tahun 2013 yaitu berjumlah 636.464 jiwa, di tahun 2014 berjumlah 651,479 jiwa, dan 2015 berjumlah 649,908 jiwa. Hal ini berarti populasi remaja di kota medan mengalami peningkatan yang cukup pesat dari tahun
2013 ke tahun 2014, dan mengalami penurunan di tahun 2015, namun tidak dalam jumlah besar.

\section{METODE}

Jenis penelitian ini adalah penelitian deskriptif yaitu suatu metode penelitian yang dilakukan dengan tujuan utama untuk mengetahui seberapa dalam pengetahuan remaja putri tentang pre menstruasi syndrome dan cara pencegahannya. Desain penelitian yang digunakan adalah Cross Sectional. Penelitian ini dilakukan di SMK Sentra Medika Medan pada bulan Januari sampai Juli 2017. Populasi dalam penelitian ini adalah semua remaja putri di SMK Sentra Medika Medan pada tahun 2017 dan sampel peneitian sebanyak 86 orang. Data penelitian diperoleh dari data primer dan data sekunder.

\section{HASIL DAN PEMBAHASAN}

1. Pengetahuan Siswa tentang PMS berdasarkan sumber informasi

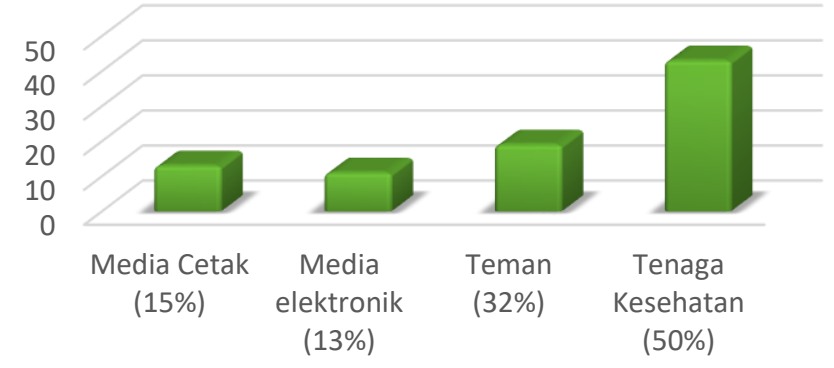

Diagram 1. Gambaran pengetahuan siswa tentang Premenstruasi Sindrome (PMS) berdasarkan sumber informasi di SMK Sentra Medika Tahun 2017 
Berdasarkan diagram 1 diketahui bahwa pengetahuan tentang PMS diperoleh siswa sebagain besar berasal dari tenaga kesehatan baik itu dokter, perawat maupun bidan yang sering melakukan kegiatan penyuluhan ke sekolah-sekolah (50\%). Selanjutnya informasi lainnya juga diperoleh dari media elektronik (13\%), media cetak (15\%) maupun orang di sekitar (teman, ibu ataupun saudara) $(32 \%)$.

2. Gambaran Pengetahuan Siswa SMK Sentra Medika tentang PMS Tahun 2017

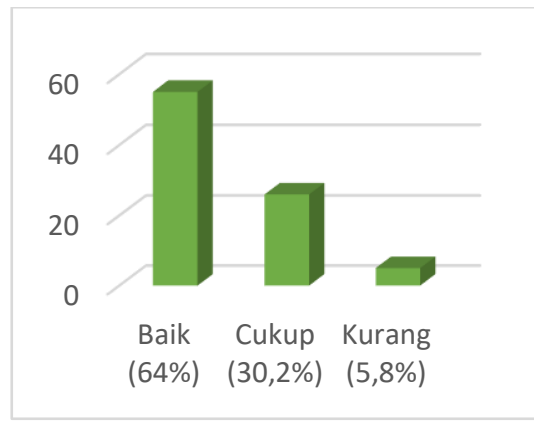

Diagram 2. Pengetahuan Siswa

SMK Sentra Medika Medan tentang PMS

Berdasarkan diagram 2 dapat diketahui bahwa mayoritas responden memiliki pengetahuan yang baik tentang premenstruasi syndrome yaitu sebanyak 55 orang (64,0\%), pengetahuan cukup sebanyak 26 orang $(30,2 \%)$ dan kurang sebanyak 5 orang $(5,8 \%)$. Hal ini menunjukkan meski sebagian besar pengetahuan remaja putri di SMK Sentra Medika Medan sudah dalam kategori baik tetapi masih ditemukan adannya pengetahuan yang kurang yaitu berjumlah 5 orang $(5,8 \%)$. Keadaan ini menjelaskan bahwa masih ada remaja putri yang tidak mengetahui tentang faktor resiko PMS.

\section{Gambaran Pengetahuan Siswa SMK} Sentra Medika tentang Pencegahan PMS.

Berdasarkan diagram 3 diketahui bahwa sebagian besar responden mengetahui cara pencegahan PMS dengan baik yaitu sebanyak 74 orang $(86,0 \%)$ dan selebihnya memiliki pengetahuan pencegahan tidak baik sebanyak 12 orang $(14,0 \%)$.

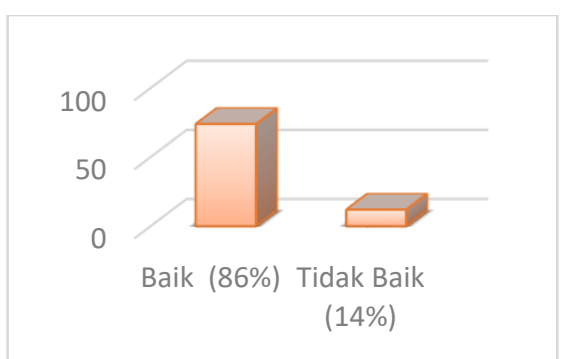

Diagram 3. Pengetahuan Siswa SMK

Sentra Medika Medan tentang PMS,

Tahun 2017

Mayoritas siswi mengetahui cara pencegahan PMS (86\%). Hal ini membuktikan bahwa responden remaja tersebut dapat mengetahui cara pencegahan PMS dan mengurangi gejala PMS dengan cara relaksasi (seperti yoga, 
dan menarik nafas dalam). Relaksasi dapat mengurangi tekanan dan mengurangi mencegah terjadinya edema dengan cara mengurangi mengonsumsi gula, garam dan karbohidrat.

Pengetahuan tentang PMS yang diperoleh oleh siswa adalah pengertian tentang PMS dan perubahan fisik yang terdapat pada gejala PMS. Sedangkan untuk pencegahan dilakukan dengan cara relaksasi dan mengurangi mengonsumsi gula garam dan karbohidrat. Pengetahuan yang kurang dapat memperberat gejala PMS dan faktor diet seperti tinggi gula, garam, kopi dan minuman bersoda dapat memperberat gejala PMS. Pengetahuan dengan cara pencegahan yang tidak baik yang terdapat pada remaja putri tentang PMS yaitu tentang mengonsumsi suplemen vitamin $\mathrm{E}$ dapat memperbaiki gejala seperti kram pada perut, dan mengatur pola makan yang teratur dan mengurangi komposisi lemak, dapat mengurangi peningkatan risiko penderita PMS. Hal ini dapat diberikan penyuluhan kesehatan kepada siswa tentang faktor diet seperti manfaat mengonsumsi suplemen vit. E dan dalam mengatur pola makan yang teratur.

\section{SIMPULAN}

Berdasarkan hasil penelitian ini dapat disimpulkan beberapa hal sebagai berikut: sebabagian besar siswi SMK Sentra
Medika Medan memiliki pengetahuan yang baik tentang Premenstruasi Syndrome yaitu sebesar $64,0 \%$. Secara umum pengetahuan responden untuk tindakan pencegahan terhadap premenstrausi syndrome juga tergolong baik yaitu sebesar $86 \%$.

\section{DAFTAR RUJUKAN}

Endri W.2014. Hubungan antara pengetahuan ibu hamil tentang tanda dan bahaya kehamilan dengan sikap dalam deteksi dini komplikasi kehamilan di wilayah Puskesmas Katasura Kabupaten Sukohorja. Jurnal Keperwatan AKPER 17 Karanganyar; 2(1).

Fahrani, F. 2014. Hubungan Tingkat Pendidikan Dengan Pengetahuan Ibu Hamil Tentang Hubungan Seksual Saat Kehamilan Di Wilayah Suka Bumi Utara. Skripsi.

Habibah, N. 2014. Gambaran Pengetahuan Ibu Hamil Tentang Penyakit Preeklampsia Di Klinik Bersalin Keluarga Husin Medan. Karya Tulis Ilmiah.

Hidayat, A. Aziz Alimul. 2011. Metode Penelitian Kebidanan \& Teknik Analisa Data. Jakarta : Salemba Medika.

Kementrian Kesehatan RI, 2013. Profil Kesehatan Indonesia Tahun 2011. Jakarta : Departemen Kesehatan

Lia Y, Sandra F. 2008. Pre-Eklampsia Berat di RSUD Bayu Asih Purwakarta. Jurnal Kesehatan Masyarakat Nasional 3(1) 
Manuaba, I, dkk. 2010. Ilmu Kebidanan, Penyakit Kandungan, dan KB Untuk Pendidikan Bidan. Jakarta : EGC.

Maryanti, R. 2013. Hubungan Usia dan Pendidikan Dengan Kejadian Preeklampsia Berat Pada Ibu Bersalin di PT.Graha Pusri Palembang. Jurnal Harapan Bangsa.

Mubaidah, S. Hubungan Pengetahuan Ibu Hamil Primigravida Trimester III Tentang Preeklampsia Dengan Upaya Pencegahan Terjadinta Preeklampsia. 2011

Notoadmodjo, S. 2012. Metodologi Penelitian Kesehatan. Edisi Revisi. Jakarta. Rineka Cipta

2010. Metodologi Penelitian Kesehatan. Jakarta : Rineka Cipta.

Nurmalichatun. 2013. Sigit Ambar Widyawati, Cahyaningrum. Hubungan Antara Primipara dan Penyakit Diabetes Melitus Pada Kehamilan Dengan Kejadian Preeklampsia Pada Ibu Hamil Di RSUD.Dr.H. Soewondo Kabupaten Kendal. Jurnal STIKES Ngudi Waluyo.

Nurulia M dkk. 2015. Hubungan Faktor Resiko dengan Kejadian PreEklampsi Berat di RSUP Dr. Mdjamil Padang. Jurnal Kesehatan Andalas, 4(2)

Oktaria D. 2015. Hubungan Status Gravida dan Usia Ibu Terhadap kejadian preeklampsia di RSUP.Dr.M. Djamil Padang Tahun 2012-2013. Jurnal Keperawatan Andalas, 4(1)

Pangemanan. 2010. Pencegahan Preeklampsia. Jurnal FK Universitas Sriwijaya..
Prasetyo, R. 2015. Hubungan Antara Karakteristik Ibu Hamil Dengan Kejadian Preeklampsia di RSUD Alhisan Kabupaten Bandung. Jurnal Prosiding Pendidikan Dokter.

Rukiyah dkk. 2010.Asuhan Kebidanan (Patologi Kebidanan). Jakarta : Trans Info Media.

Survei Demografi dan Kesehatan Indonesia. 2012. Angka Kematian Ibu Melahirkan. Jakarta.

Sukarni, 2013. Buku Ajar Keperawatan Maternitas. Edisi I. Yogyakarta. Nuha Medika;

Sudibyo S, R. Metodologi riset keperawatan. Edisi I. Jakarta. Trans Info Media.

World Health Organization. 2012. Angka Kejadian Preeklampsia.. 